\title{
OPINION 974
}

\section{PAPILIO AGLAJA LINNAEUS, 1758 (INSECTA, LEPIDOPTERA): REFUSAL TO USE THE PLENARY POWERS}

RULING.- (1) The use of the plenary powers to validate the name Papilio aglaja Linnaeus, 1758, for a Pierid species is hereby refused.

(2) The following specific names are hereby placed on the Official List of Specific Names in Zoology with the Name Numbers specified:

(a) aglaja Linnaeus, 1758, as published in the binomen Papilio aglaja (Nymphalidae) (Name No. 2469);

(b) pasithoe Linnaeus, 1767, as published in the binomen Papilio pasithoe (Name No. 2470).

(3) The specific name aglaja Linnaeus, 1758, as published in the binomen Papilio aglaja (Pieridae) (a junior homonym of Papilio agalaja Linnaeus, 1758 (Nymphalidae)) is hereby placed on the Official Index of Rejected and Invalid Specific Names in Zoology with the Name Number 970.

\section{HISTORY OF THE CASE (Z.N.(S.) 1791)}

The present case was submitted to the office of the Commission by Lt.-Col. C. F. Cowan in February 1967. The application was sent to the printer on 22 February 1967 and was published on 30 June 1967 in Bull. zool. Nomencl. 24 : 186-189. Public Notice of the possible use of the plenary powers in the present case was given in the same part of the Bulletin as well as to the other prescribed serial publications (Constitution Art. 12b; Bull. zool. Nomencl. 21 : 184) and to eight entomological serials.

The proposals were opposed by Mr. C. F. dos Passos and Mr. B. C. S. Warren (Bull. zool. Nomencl. $25: 68-71$ ), whose arguments, however, were not in accordance with the Code, and the use of the plenary powers would also be necessary to achieve their objective. Mr. N. D. Riley and Mr. L. G. Higgins (ibid. $26: 4-6$ ) proposed that the normal application of the Code be applied. Further comments by Messrs. Cowan, dos Passos \& Warren were published in Bull. zool. Nomencl. $26: 2-4 ; 67-68 ; 186$. Dr. C. W. Sabrosky (ibid. $27: 69$ ) pointed out the irrelevance of much of the argument in the present case.

\section{DECISION OF THE COMMISSION}

On 22 March 1971 the Members of the Commission were invited to vote under the Three-Month Rule on Voting Paper (67)7, in part 1 either for or against the use of the plenary powers in the present case, and in part 2, for either Alternative B (as set out by Cowan, Bull. zool. Nomencl. 24 : 188-189-suspension of Art. 53) or Alternative B (as set out by Cowan, Bull. zool. Nomencl. 26 : 186 - suppression of the Nymphalid aglaja). It was pointed out that a negative vote in part 1 of the Voting Paper would imply acceptance of the proposals of Riley and Higgins, Bull. zool. Nomencl. $26: 6$. At the close of the prescribed voting period on 22 June 1971 the state of the voting was as follows: 
Part 1. Affirmative votes-three (3), received in the following order: Vokes, Tortonese, Bonnet

Negative votes-thirteen (13): Mayr, Holthuis, Melville, Lemche, Simpson, Alvarado, Eisenmann, Sabrosky, Jaczewski, Binder, Kraus, Brinck, Starobogatov

Part 2. For Alternative A-four (4): Mayr*, Vokes, Tortonese, Bonnet For Alternative B-one (1): Lemche*

Voting Papers not returned-three (3): Forest, Munroe, Ride

The following comments were made by Commissioners in returning their votes:

Prof. E. Mayr (5.iv.71): "The application for this vote was poorly prepared and poorly edited. There is no page or line priority, and the first reviser principle has always been one of the foremost nomenclatural principles for Linnaeus. Therefore, the validity of aglaja for the Nymphalid is beyond question. The only question then before the Commission is whether replacement of the name aglaja for the Pierid by pasithoe would or would not cause sufficient confusion to necessitate suspension of Article 53 in the present case. This would be no major tragedy since the species involved are now placed in different families, but it would have to be demonstrated that this was a necessary action for the sake of stability of lepidopteran nomenclature. Unfortunately, there was not an adequate discussion of this question in the various comments on this case."

Dr. C. W. Sabrosky (17.v.71): "In addition to confusion over the meaning of 'first reviser', much of the argument stems from the premise that the second of the two species named Papilio aglaja in 1767, i.e. No. 140 (the Palearctic nymphalid), is of course the junior primary homonym. Verity (1935), Hemming (1942), and others so interpreted it, and all seem to accept Hemming's statement 1967, quoted by Cowan (Bull. $26: 2$, par. 4) about the 'introduction [italics mine] ... in 1961 of the First Reviser principle for dealing with cases of this kind.'

"I believe that one could demonstrate that the premise was erroneous under the old Rules as well as under the new Code. Certainly for simultaneously published synonyms, the first International Rules (Article 28) unquestionably placed the First Reviser rule superior to a recommendation for page precedence, It would have been only logical to have considered that such a First Reviser rule would likewise have been applied to simultaneously published homonyms; in both the critical point is the same: simultaneous publication of two (or more) names. Incidentally, the attitude of at least some of the authors who followed page precedence for cases of homonymy was probably influenced by the fact that they followed page precedence for synonymy also, to the extent of changing a clear decision by a first reviser, in contradiction to the clear and definite rule in old Article 28!

" $\mathrm{Be}$ that as it may, the 1961 Code is retroactive to 1758 in this area, and the situation is clear: First Reviser rule applies in both homonymy and synonymy

\footnotetext{
* Conditional on a majority for use of the plenary powers in Part 1.
} 
(Art. 24a). I agree with the conclusions and proposals of Riley and Higgins (Bull. 26 : 5-6, par. 7-9)."

\title{
ORIGINAL REFERENCES
}

The following are the original references for names placed on the Official List and Index by the Ruling given in the present Opinion:

aglaja, Papilio, Linnaeus, 1758, Syst. Nat. (ed. 10) $1: 481$ (Nymphalidae) aglaja, Papilio, Linnaeus, 1758, Syst. Nat. (ed. 10) $1: 465$ (Pieridae)

pasithoe, Papilio, Linnaeus, 1767, Syst. Nat. (ed. 12) $1: 755$

\section{CERTIFICATE}

I certify that the votes cast on Voting Paper (71)7 were cast as set out above, that the proposal contained in that Voting Paper for the use of the plenary powers was not adopted, and that the decision so taken, being the decision of the International Commission, is truly recorded in the present Opinion No. 974.

\author{
R. V. MELVILLE \\ Secretary \\ International Commission on Zoological Nomenclature
}

London

16 September 1971 


\section{$2 \mathrm{BHL}$ Biodiversity Heritage Library}

International Commission on Zoological Nomenclature. 1971. "Papilio aglaja Linnaeus, 1758 (Insects, Lepidoptera): refusal to use the plenary powers." The Bulletin of zoological nomenclature 28, 151-153. https://doi.org/10.5962/bhl.part.6125.

View This Item Online: https://www.biodiversitylibrary.org/item/44470

DOI: https://doi.org/10.5962/bhl.part.6125

Permalink: https://www.biodiversitylibrary.org/partpdf/6125

\section{Holding Institution}

Natural History Museum Library, London

\section{Sponsored by}

Natural History Museum Library, London

\section{Copyright \& Reuse}

Copyright Status: In copyright. Digitized with the permission of the rights holder.

License: http://creativecommons.org/licenses/by-nc-sa/3.0/

Rights: https://biodiversitylibrary.org/permissions

This document was created from content at the Biodiversity Heritage Library, the world's largest open access digital library for biodiversity literature and archives. Visit BHL at https://www.biodiversitylibrary.org. 